Int. J. Mol. Sci. 2005, 6, 3-10

International Journal of

Molecular Sciences

ISSN 1422-0067

(C) 2005 by MDPI

www.mdpi.org/ijms/

\title{
Marvin Charton - Correlation Analyst Par Excellence
}

\section{John Shorter}

29A, Meadowfields, Whitby, North Yorkshire, YO21 1QF, UK. (Emeritus Reader in Chemistry, University of Hull), email: johnshorter@hotmail.com

Received: 10 September 2004 / Accepted: 19 October 2004 / Published: 31 January 2005

\begin{abstract}
Since the late 1950s Marvin Charton, physical organic chemist, of Pratt Institute, Brooklyn, New York has studied structure-property relationships through correlation analysis, and has become one of the leading authorities in this field.
\end{abstract}

Keywords: Hammett equation, correlation analysis, linear free energy relationships, substituent effects and constants, biological activity.

\section{Introduction}

Marvin Charton, of Pratt Institute, Brooklyn, New York, describes his research interests in his CV as follows: "The study of structure-property quantitative relationships in chemistry and biology by means of correlation analysis. Applications of this work include chemical reaction mechanisms, the estimation of chemical and physical properties and chemical reactivities of chemical compounds, the design of bioactive molecules including medicinal drugs and pesticides, and the prediction of environmental toxicities and other properties." His first paper in this field appeared in 1958 and he has now published over 150 research papers and review articles.

Marvin's forebears came to the USA from eastern Europe in the late 19th century. His surname may sound French, but his ancestry was Polish, and the relatives who came from Poland to America had the name of Charton. He sometimes suggests, half in fun, that one of his ancestors may have accompanied Napoleon from France to Moscow in 1812, but during the great retreat, by the time they reached Poland he was a little tired of marching, so he absented himself, and found a good place to live and a nice Polish girl to marry....

Marvin was born in New York City on May 1, 1931, and grew up near the Bronx Zoo (then the N.Y. Zoological Park, now part of the Wildlife Conservation Center). This seems to have stimulated an early interest in science; he not only admired the animals in the zoo, but brought home mice, 
tadpoles and insects that were not part of the collection. Marvin attended Bronx High School of Science, a scholarship school and part of the then excellent N.Y. city school system. He took his B.S. in 1953 at the City College of New York (the undergraduate school of no less than eight future Nobel Prize winners). His M.A. was from Brooklyn College (a part of the City University of New York, CUNY) in 1956, and his Ph.D. from Stevens Institute of Technology, Hoboken, New Jersey, was awarded in 1962. Like many aspiring young chemists in those days, for some years Marvin had his own lab at home. On one occasion he caused a sensation in his neighbourhood in the Bronx, when the lab in his bedroom had a problem: a bottle of thionyl chloride dissolved its stopper and started to fume. Marvin was not at home and his father put the bottle out on the fire escape; a neighbour saw the fumes, assumed the apartment was on fire and called the New York Fire Department!

During his college years, Marvin met his future wife Barbara, and a few words from her would be appropriate. "We met in Brooklyn College in 1953; he was the TA teaching the freshman class I was in.... insisted that he dismantle the lab at home and throw away the pickled snakes before we were married in 1955. He worked briefly in industry in 1955, synthesizing and doing kinetic studies on sulfur compounds for Evans Chemetics Inc. The firm specialized in thioglycolic acid derivatives and I, for one, was delighted when he ceased to work there - he stank! He started teaching at the Pratt Institute in January 1956 and obviously never left. His first appearance at an ACS National Meeting was in September 1956, the corresponding paper was published in JACS in 1958."

Marvin Charton was appointed Instructor of Chemistry at Pratt Institute, Brooklyn in 1956, Assistant Professor in 1961, Associate Professor in 1964 and Professor of Chemistry in 1967, a position he holds to the present day. His only other long-term appointment has been as a Visiting Professor from 1986 in the Polymer Research Institute of the Polytechnic University of Brooklyn, although he has been a short-term Visiting Professor at various universities and colleges, in North America, Europe, and Asia. The nature of the Institute to which he has devoted his entire professional life has exerted a considerable formative influence on his research career. This has not been that of a typical American physical organic chemist of the second half of the 20th century. Marvin Charton has not had the opportunity to engage in substantial experimental research, through founding a research school of students and post-docs. Pratt has been essentially a teaching institution during the time Marvin has been associated with it, at least as far as science is concerned. Marvin's expertise has been to examine exhaustively the literature of physical organic chemistry, as it has developed in the last sixty years or so, and to draw from it experimental data for theoretical treatment by the methods of linear free energy relationships (LFER), as they were formerly called. In their contemporary expanded form, they are now more appropriately referred to as the methods of correlation analysis.

Marvin has thus not been dependent on Pratt Institute's provision of research laboratory facilities for organic or physical chemistry. He has required facilities to enable him to do large numbers of calculations, initially those of simple linear regression, and later of multiple regression and of other more sophisticated statistical techniques. The facilities he has needed have advanced from desk electrical calculating machines (perhaps log tables or mechanical calculators at the beginning!) to the mainframe computer, to the desktop PC, and then on to the laptop and other portable forms of computers. Even in the early days, he preferred to do as much as possible of his work at home rather than in his college office, and in more recent years his study has effectively become his research laboratory. 
Marvin is the sole author of almost all his early papers, although Barbara was of course always present in a supportive role. In the early days she was naturally much occupied with their three children, but as time went on she began to feature as co-author of some of the papers. Also, as Marvin became better known and his expertise and assistance were increasingly valued, he began to attract 'collaborators at a distance', in other institutions and sometimes even in other countries, and this has often led to joint authorship of publications. These collaborations at a distance became even more important as Marvin developed interests in biological activity.

I shall now present a general survey of his publications and outline the main themes of his researches, in the context of the growth of physical organic chemistry in the second half of the $20^{\text {th }}$ century (only selected references will be given).

\section{The Research Work of Marvin Charton}

Charton began research in linear free energy relationships at a critical time in the development of the subject. Hammett had presented his eponymous rho-sigma equation for the reactivities of metaand para-substituted benzene derivatives in 1937 and his book "Physical Organic Chemistry" had appeared in 1940. The late 1940s saw an increasing interest in physical organic chemistry in general, and especially in linear free energy relationships. H.H. Jaffé's 1953 article on the Hammett Equation, in Chemical Reviews, aroused great interest, since he found many more examples of the application of this equation than had been presented by Hammett himself. Also there were systems to which the Hammett equation might have been expected to apply, but did not work well. The article stimulated many workers to try to modify the Hammett equation to improve its performance or to apply Hammett-type treatments to systems other than meta- and para-substituted benzene derivatives. Starting in 1952-56, R.W. Taft pioneered the treatment of the reactivities of ortho-substituted benzene systems and of aliphatic systems, and within a year or so was publishing extensively on the separation of substituent effects into inductive and resonance components. Charton was certainly stimulated by his study of the work of Jaffé and of Taft.

Charton's first paper (1958, co-authored with his supervisor H. Meislich) was on the Application of the Hammett Equation to Non-Aromatic Unsaturated Systems, namely trans-3-substituted acrylic acids [1]. During the next 15 years, under the same general title, Charton extended such treatment to substituted acetylenes, trans- and cis-vinylenes, vinylidenes, and heterovinylidenes, the Diels-Alder reaction, ionization potentials, electrophilic and nucleophilic addition to olefins, and physical properties and the reactivity of the ethynyl proton. Towards the end of the series, Parts IX and X were co-authored with Barbara Charton. In 1973 Charton summarized this work (with some extension) in an article of over 120 pages in Progress in Physical Organic Chemistry [2], thereby establishing a pattern of publication which he has followed on several occasions.

During the period 1958-73 the form of the treatments applied by Charton developed considerably. Notably he adopted multiparameter treatments involving multiple regression on substituent inductive and resonance constants as introduced by Taft, in preference to linear regression on composite substituent constants of the Hammett type. It was not long before Charton developed his own sets of inductive and resonance parameters, often differing slightly from those proposed by Taft, although they were represented by essentially the same symbols, $\sigma_{I}$ and $\sigma_{R}$. As early as 1964 Charton published a paper on The Definition of Inductive Substituent Constants, which was much cited for many years 
[3]. (Much later came a 130 page article in Prog. Phys. Org. Chem. on Electrical Effect Substituent Constants for Correlation Analysis, one of his most cited articles [4]). Charton's Extended Hammett Equation emerged as a rival to Taft's Dual Substituent-Parameter Equation. During this period Charton published many other papers not part of any series, but he had already begun another substantial series, on the Ortho Effect.

This had been, in fact, the subject of his second paper: Application of the Hammett Equation to Ortho-Substituted Benzene Reaction Series, published in 1960 [5]. This was followed over the next few years by some isolated papers on the same topic, including one (with Barbara Charton) in 1968 on The Variation of the Ortho Electrical Effect with Solvent [6]. Shortly after this, a long coherent series on The Nature of the Ortho Effect began [7], covering the effects of substituents on the rates of various reactions, particularly of carboxylic acids and their esters, but also dealing with structural effects on other properties including ionization potentials, polarographic half-wave potentials, and NMR spectra. The possibility of defining ortho substituent constants of general applicability was also discussed. The emphasis on ester reactions inevitably led to disagreements with some aspects of Taft's work, particularly the significance of the $\mathrm{E}_{\mathrm{s}}$ parameter for ortho-substituents as a measure of steric effect. The series on the Ortho Effect was wound up in 1971 with a summarizing article of about 80 pages in Prog. Phys. Org. Chem. [8].

A year or so later (1975) saw the start of another long series, this time on Steric Effects [9], which eventually extended to thirteen parts, and included such topics as ester reactions (again), nucleophilic substitution, elimination, barriers to internal rotation, hydrolysis of amides and related compounds, the definition and measurement of upsilon constants, racemization of chiral biphenyls, substituents at oxygen, nitrogen, sulfur and phosphorus, and the composition of the steric parameter as a function of alkyl branching [10].

This list of topics gives some indications of the developments that had by this time (1976-1978) occurred in Charton's approach to the application of correlation analysis in physical organic chemistry. Upsilon ( $v$ ) is the steric parameter which Charton began to develop around 1970 [11,12], that has become a rival to Taft's $E_{s}$ for use in multiparameter treatments of substituent effects. The interest in the effects of groups involving substituents at elements other than carbon has been pursued by Charton in quite a few papers [13]. In disagreement with many other authors, Charton considers that special scales of substituent constants are not required for such substituents. Charton has had a special interest in the structural effects of alkyl substituents and has been highly sceptical of the significance of Taft's $\sigma^{*}$ values for such groups $[14,15]$.

From the late 1970s Charton began to attract 'collaborators at a distance', who sought to make use of his expertise in the correlation analysis of substituent effects. In the early 1980s he joined in the work of Chapman and Shorter's research group in Hull on the rates of reaction of a large number of ortho-substituted benzoic acids with diazodiphenylmethane in a wide range of solvents, a collaboration which led to several papers $[16,17]$. A short time earlier he had contributed a long chapter on the Applications of Linear Free Energy Relationships to Polycyclic Arenes and to Heterocyclic Compounds in the Chapman-Shorter volume on "Correlation Analysis in Chemistry - Recent Advances," [18]. A further example is provided by his collaboration with Tomasik and other Polish authors in 1985 on the Ortho Effect in pyridines [19].

In 1975 Charton attended a Gordon Conference in the field of biological activity. The experience stimulated his interest in trying to transfer his expertise in correlation analysis from physical organic 
chemistry to the area of biological activity, specifically Quantitative Structure-Activity Relationships. It is evident that many members of the network of specialists in biological activity with whom he came into contact through the Gordon Conference welcomed his interest and the opportunity to make use of his expertise then and thereafter. In time this generated some research collaborations at a distance, but it was more fruitful in the short term in invitations to write articles in volumes of biological interest. Thus Charton's first contribution to the biological field was in 1977, with an article on substituent effects on chemical lability, for a volume entitled "Design of Biopharmaceutical Properties through Prodrugs and Analogs," published by the American Pharmaceutical Society [20]. However, he soon began to publish research papers which essentially drew data from the literature of biological activity, in a way analogous to what he had done with the literature of physical organic chemistry for many years. For instance, there were papers on The Correlation of Biological Activities for Alkyl Substituted Systems (1981) [21], Protein Folding and the Genetic Code - An Alternative Quantitative Model (1981) [22], The Structural Dependence of Amino Acid Hydrophobicity Parameters (1982) [23], Prodrug Lability Prediction through the Use of Substituent Effects (1985) [24], and (notably) The Quantitative Description of Properties and Bioactivities of Amino Acids, Peptides and Proteins (1990) [25] . Over thirty of Charton's research papers and articles in the last quarter century may be classified as biological. Barbara Charton has collaborated in some of these [23].

Charton's interest in the biological field has not led to neglect of physical organic chemistry. His most important contribution in the last 20 years or so has been the development since 1987 of what he calls a general treatment of electrical effects. This involves a triparametric relationship, the LDR equation, whose explanatory variables are localized and delocalised electrical effect parameters related to the inductive and resonance constants of earlier treatments, and also a parameter representing the sensitivity of the substituent to change in electronic demand by the active site. Charton claims that this treatment is more successful and simpler to apply than the earlier treatments. It was first presented in an article in Prog. Phys. Org. Chem. [26], and has subsequently featured in further papers by Charton $[27,28]$.

Another major concern in recent years has been the mode of transmission of electrical effects. A series of studies has led him to conclude that the classical model of the so-called inductive effect is outmoded and should be replaced by a field effect model [29,30,31]. He has also been interested in expressing structural effects, particularly steric effects, by topological parameters [32,33,34].

The articles which Charton has written for Prog. Phys. Org. Chem. have already been mentioned. He has also been a major contributor since 1970 to the series "The Chemistry of Functional Groups," produced by Saul Patai. Thus he has written substantial accounts of substituent effects in chapters on the Olefinic Properties of Cyclopropanes [35]; Triply Bonded Groups [36]; Doubly Bonded Groups [37]; Chalcogen Substituents [38]; Arsenic, Antimony and Bismuth Groups [39]; Germanium, Tin and Lead Groups (on two occasions) [40,41]; Dienes and Polyenes [42]; and Organolithium Compounds [43]. Each of these articles has been an opportunity for him to apply his currently favoured methods of correlation analysis to a new area. In recent years Charton has himself started to edit a series of volumes, namely Advances in Quantitative Structure Property Relationships, which has now reached Volume 3 (2002).

To sum up Charton's achievements in applying correlation analysis to the quantitative data of organic chemistry: he has been one of the pioneers in using the technique to develop and refine basic concepts of physical organic chemistry. Thus nobody working in this field today can ignore Charton's 
approach to the meanings of such terms as 'inductive' and 'resonance' in relation to substituent effects. The great success of correlation analysis in physical organic chemistry is all the more remarkable because it has often involved the use of data which were not measured specifically for treatment in this way. In this situation the correct use of statistical procedures has been very important. This is a key feature of Charton's researches, but is regrettably not always adopted by other workers.

\section{My Friendship with the Chartons}

I first met Marvin early in 1967. For a few years previous to this we had exchanged reprints and some correspondence. In 1966-67 I was R.T. French Visiting Professor of Chemistry at the University of Rochester, NY, and in March 1967 we had a family visit to New York City. We spent one afternoon visiting the Chartons in their apartment on Brooklyn Heights, with its views across the East River to the south end of Manhattan and to the Statue of Liberty. The wives took the three Charton children (Michael, Sarah and Debby) and the three Shorter children (Christopher, Stephen and Caroline) to a park (the children were all of much the same age), while Marvin and I talked chemistry. I met Marvin and Barbara again about a year later at the Second Conference on Linear Free Energy Correlations held at the University of California, Irvine; we spent much time together, as became our custom at many later conferences. I met them again at the next two conferences in the series, in the Spring of 1971 at Tallahassee and in January 1974 in San Juan, Puerto Rico. On both these trips I spent a few days with the Chartons in Brooklyn Heights.

In July 1975 I was with Marvin at the Gordon Conference already mentioned and stayed with the Chartons afterwards for several days; Marek Krygowski was also there. Marvin, Marek and I made a pilgrimage to visit Professor and Mrs. Louis Hammett in their retirement community in New Jersey [44]. The Chartons' generous hospitality to physical organic chemists visiting the USA was now well established and many and long were the discussions in their living room. People were beginning to talk about the 'Brooklyn Heights Meetings' in Correlation Analysis in Organic Chemistry! One important development in which the meeting of Marvin, Marek and I in 1975 certainly played a part was the start of international conferences in Correlation Analysis in (Organic) Chemistry in Europe (later extended to Asia) and the foundation of the International Group for Correlation Analysis in (Organic) Chemistry (IGCAIC), the story of which has recently been told by me in a paper dedicated to Marek Krygowski [45].

In mid-August 1976 all the Chartons came to England and stayed with us in Hull. A week or two later Marvin and Barbara travelled to La Grande Motte, near Montpellier, France, for the Third IUPAC Conference in Physical Organic Chemistry, with Sarah and Debby as their 'accompanying persons' (Michael had had to return to the USA). I travelled out to the conference, with Caroline as my accompanying person. The three teenage girls had a great time together, particularly on the conference outings, when they exhibited a slight tendency (in the view of their parents) to be a little cheeky to distinguished professors, who did not, however, seem to mind!

By 1976 there had thus been established professional and personal relationships between Marvin and Barbara and myself in a pattern which has continued to the present day: my visits to Brooklyn Heights, their visits to my home in Hull, and later Beverley and Whitby, and forgatherings at conferences in the USA, UK, continental Europe and Asia, particularly those under the auspices of IUPAC and IGCAIC. I have come to value their friendship very greatly. Over the long period we have 
now known each other we have been in many wonderful places together and there enjoyed many wonderful experiences: Assisi, Brno, Chennai (Madras), Edinburgh, Fukuoka, Jerusalem, New York, Paris, Poland, Prague, Washington DC, Yorkshire....; visits to beauty spots, cathedrals, churches, concerts, museums, operas, temples...... but we will not forget that we have also been stimulated by some very useful conferences and encounters with many other colleagues.

I recall from many years ago a physical organic colleague, who was rather on the edge of the correlation analysis community, saying to me, "You experts in correlation analysis seem often to have such vigorous disputes and disagreements in your specialism and yet you all seem to be such very good friends!" He was indeed quite right!!

\section{References}

1. Charton, M.; Meislich, H. J. Am. Chem. Soc. 1958, 80, 5940-5943.

2. Charton, M. Prog. Phys. Org. Chem. 1973, 10, 81-204.

3. Charton, M. J. Org. Chem. 1964, 29, 1222-1227.

4. Charton, M. Prog. Phys. Org. Chem. 1981, 13, 119-251.

5. Charton, M. Can. J. Chem. 1960, 38, 2493-2499.

6. Charton, M.; Charton, B.I. J. Org. Chem. 1968, 33, 3872-3878.

7. Charton, M. J. Org. Chem. 1969, 34, 278-285.

8. Charton, M. Prog. Phys. Org. Chem. 1971, 8, 235-317.

9. Part I, Charton, M. J. Am. Chem. Soc. 1975, 97, 1552-1556.

10. Part XIII, Charton, M. J. Org. Chem. 1978, 43, 3995-4001.

11. Part VII, Charton, M. J. Org. Chem. 1976, 41, 2217-2220.

12. Charton, M. Topics Curr. Chem. 1983, 114, 57-91.

13. Charton, M. J. Org. Chem. 1969, 34, 1877-1881, 1882-1885.

14. Charton, M. J. Am. Chem. Soc. 1977, 99, 5687-5688.

15. Charton, M. J. Org. Chem. 1979, 44, 903-906.

16. Aslam, M.H.; Burden, A.G.; Chapman, N.B.; Shorter, J.; Charton, M. J. Chem. Soc., Perkin Trans. 2 1981, 500-508.

17. Aslam, M.H.; Chapman, N.B.; Shorter, J.; Charton, M. J. Chem. Soc., Perkin Trans. 2 1981, 720724.

18. Charton, M. In Correlation Analysis in Chemistry - Recent Advances; Chapman, N.B.; Shorter, J., Ed.; Plenum: New York, 1978; pp. 175-268.

19. Charton, M.; Gawinecki, R.; Rasała, D.; Kraus, W.; Tomasik, P. Chem. Scripta 1985, 25, 350355.

20. Charton, M. In Design of Biopharmaceutical Properties through Prodrugs and Analogs; Roche, E.B., Ed.; American Pharmaceutical Society: Washington D.C., 1977; pp. 228-280.

21. Charton, M. In Proceedings of the Third Congress of the Hungarian Pharmacological Society, Budapest, 1979; Akademiai Kiado: Budapest, 1980; pp. 211-220.

22. Charton, M. J. Theoret. Biol. 1981, 91, 115-123.

23. Charton, M.; Charton, B.I. J. Theoret. Biol. 1982, 99, 629-644.

24. Charton, M. In Drug and Enzyme Targeting, Vol. 112, Part A, Methods in Enzymology; Widder, K.J.; Green, R., Eds.; Academic Press: New York, 1985; pp. 323-340. 
25. Charton, M. Prog. Phys. Org. Chem. 1990, 18, 163-284.

26. Charton, M. Prog. Phys. Org. Chem. 1987, 16, 287-315.

27. Charton, M.; Charton, B.I. Bull. Soc. Chim. Fr. 1988, 199-210.

28. Charton, M. Adv. Quant. Struct. Prop. Rel. 1996, 1, 171-219.

29. Charton, M. J. Phys. Org. Chem. 1999, 12, 275-282.

30. Charton, M.; Charton, B.I. J. Chem. Soc., Perkin Trans. 2 1999, 2203-2211.

31. Charton, M.; Charton, B.I. J. Phys. Org. Chem. 2001, 14, 832-838.

32. Charton, M. In Similarity Models in Organic Chemistry, Biochemistry and Related Fields; Zalewski, R.I.; Krygowski, T.M.; Shorter, J., Eds.; Elsevier: Amsterdam, 1991; pp. 629-687.

33. Charton, M. J. Computer-Aided Mol. Design 2003, 17, 197-209.

34. Charton, M.; Charton, B.I. J. Computer-Aided Mol. Design 2003, 17, 211-221.

35. Charton, M. In Chemistry of the Alkenes, Vol. 2; Zabicky, J., Ed.; Wiley: New York, 1970; pp. 511-610.

36. Charton, M. In Chemistry of the Functional Groups, Supplement C, The Chemistry of Triple Bonded Functional Groups; Patai, S., Ed.; Wiley: New York, 1983; pp. 269-323

37. Charton, M. In The Chemistry of the Functional Groups, Supplement A, The Chemistry of Double Bonded Functional Groups, Vol.2, Part 1; Patai, S.; Rappoport, Z., Eds.; Wiley: New York, 1989; pp. 239-298.

38. Charton, M. In The Chemistry of Sulfenic Acids, Esters and Derivatives; Patai, S., Ed.; Wiley: New York, 1990; pp. 657-700.

39. Charton, M. In The Chemistry of Arsenic, Antimony and Bismuth; Patai, S., Ed.; Wiley: New York, 1994; pp. 367-439.

40. Charton, M. In The Chemistry of Organic Germanium, Tin and Lead Compounds; Patai, S., Ed ; Wiley: Chichester, 1995; pp. 603-664.

41. Charton, M. In The Chemistry of Germanium, Tin and Lead Compounds, Vol. 2; Rappoport, Z., Ed.; Wiley: Chichester, 2002; pp. 537-578.

42. Charton, M. In The Chemistry of Dienes and Polyenes; Rappoport, Z., Ed.; Wiley: Chichester, 1997; pp. 683-732.

43. Charton, M. In The Chemistry of Organolithium Compounds, Part I; Rappoport, Z., Ed.; Wiley: Chichester, 2004; Chap. 7.

44. Shorter, J. Prog. Phys. Org. Chem. 1990, 17, 1-29. (A Hammett Memorial Lecture).

45. Shorter, J. J. Phys. Org. Chem. 2003, 16, 645-654.

(C) 2005 by MDPI (http://www.mdpi.org). 